\title{
Komentarz do stanowiska ekspertów: „Leczenie antyagregacyjne u pacjentów z ostrym zespołem wieńcowym — zalecenia dla zespołów ratownictwa medycznego"
}

\author{
Prof. dr hab. n. med. Jarosław Kaźmierczak \\ Konsultant Krajowy w dziedzinie kardiologii \\ Klinika Kardiologii, Pomorski Uniwersytet Medyczny, Szczecin
}

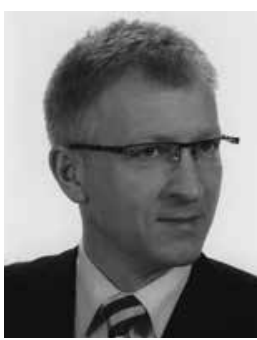

Opublikowane w „Kardiologii Polskiej” stanowisko ekspertów dotyczące stosowania leczenia przeciwpłytkowego w początkowych stadiach ostrego zespołu wieńcowego (ACS), przeznaczone głównie dla zespołów ratownictwa medycznego, to bardzo ważny dokument. Przedstawia ono aktualną wiedzę w tym zakresie i zalecenia dostosowane do naszych warunków.

W 2016 r. w Polsce ok. 127 tys. pacjentów zachorowało na ACS, z tego 28 tys. na zawał serca $z$ uniesieniem odcinka ST (STEMI), prawie 43 tys. na zawał serca bez uniesienia odcinka ST (NSTEMI) i pond 56 tys. na niestabilną dławicę piersiową (UA). Wczesnemu leczeniu zabiegowemu (pierwotne przezskórne interwencje wieńcowe) poddano odpowiednio 90\% (STEMI), 68\% (NSTEMI) i 60\% (UA) pacjentów. Wczesne leczenie reperfuzyjne ma olbrzymie znaczenie dla zmniejszenia śmiertelności, zarówno wewnątrzszpitalnej, jak i odległej — wieloletniej, podobnie jak dla ograniczenia liczby chorych z pozawałową niewydolnością serca. "Czas to serce" - to jedna z podstawowych zasad współczesnego leczenia ACS.

Postępowanie przedszpitalne przy pierwszym kontakcie medycznym ma decydujący wpływ na dalsze losy chorego. Po pierwsze - prawidłowe rozpoznanie typu ACS (wsparcie telemedyczne - ocena elektrokardiogramu i konsultacja kardiologa), ocena ryzyka (przy NSTEMI i UA) oraz szybki transport pacjenta na odpowiedni oddział. Tutaj chciałbym dodać uwagę do ryciny 1 zaprezentowanej w komentowa- nym artykule — jeśli od miejsca zachorowania najbliżej jest do oddziału kardiologicznego z 24-godzinnym dyżurem hemodynamicznym, to nawet chorzy z NSTEMI i UA umiarkowanego oraz niskiego ryzyka powinni być tam transportowani. Po drugie - szybkie, już w miejscu zachorowania, wdrożenie optymalnej terapii. Tutaj najważniejsze jest właśnie leczenie antyagregacyjne i przeciwbólowe. Istnieją solidne podstawy teoretyczne i wiele wyników badań klinicznych przemawiających za jak najszybszym wdrożeniem leków przeciwpłytkowych - zastosowaniem terapii podwójnej, tj. kwasu acetylosalicylowego i jednego z antagonistów receptora P2Y12 (z preferencją tikagreloru), jednak wczesne stosowanie antagonistów receptora P2Y12 ma w zaleceniach Europejskiego Towarzystwa Kardiologicznego poziom wiarygodności B. Udowodniono natomiast, że wykorzystanie tych leków w okresie przedszpitalnym jest bezpieczne. Dwie grupy chorych wymagają szczególnej uwagi: pacjenci ze STEMI i osoby z NSTEMI-ACS bardzo wysokiego ryzyka, którzy z dużym prawdopodobieństwem będą wymagali pilnego leczenia zabiegowego. Należy podkreślić, że rozporządzenie Ministra Zdrowia z dnia 20 kwietnia 2016 r. zezwala na podanie klopidogrelu lub tikagreloru przez ratowników medycznych po teletransmisji zapisu elektrokardiograficznego i konsultacji z kardiologiem. Obecnie w wielu województwach trwa akcja wdrożenia do codziennej praktyki stosowania tikagreloru w zespołach ratownictwa medycznego.

Konflikt interesów: honoraria za udział w komitecie doradczym AstraZeneca 